ESSAY ROUNDTABLE

\title{
THE CATEGORY “LEGAL THEOLOGY" AND THE STUDY OF CHRISTIAN LAWS
}

\author{
NORMAN DOE
}

Professor of Law and Director of the Centre for Law and Religion, Cardiff University

KEYWORDS: Church law, ecclesiastical law, theology, legal theology

Theology, the study of God, consists of a network of subdisciplines: biblical theology, moral theology, ecumenical theology, and so on. Each branch of theology has its own distinctive object of study, methods, and purposes. For example, pneumatology studies the Holy Spirit, practical theology uses the pastoral cycle, and liberation theology seeks to transform unjust societal structures that oppress the marginalized. Each branch of theology has its own distinctive community of scholars. It is a common view (though perhaps a contested one, as between the different church traditions) that the main purpose of Christian theology is to proclaim the Gospel of Christ. The branches of theology, in turn, are vehicles for each of this core purpose. Legal theology could become a branch of theology with its own distinctive objects of study, methods, and purposes. What follows explores these themes, how the subdiscipline of legal theology might be defined and developed in the context of the study of the systems of law, order, and polity, of churches across the Christian traditions that deal with, for example, forms of regulation, ministry (lay or ordained), governance (institutions and functions), discipline, doctrine, worship, rites, property, and external relations. ${ }^{\mathrm{I}}$ It does so as to the following. (I) The object of study: legal theology should at its core be about the relationship between theology and church law-more particularly, the relationship between church law and each of the other branches of theology. (2) The method of study: legal theology may involve the theological study of church law and/or the legal study of theology using standard juristic methods (such as text and context, critical, historical, analytical) as well as methods used in the other branches of theology (3) The purpose of study: the development of a community of scholars collaborating with a view to its impact on ecclesial practice. Theology is indispensable to a full understanding of the place of law in the life of the church; and law provides evidence to test the propositions of theology in the practical life of the church as this is translated through norms to action.

\section{THE OBJECTS OF STUDY: TOPICS FOR LEGAL THEOLOGY}

The topics of well-established branches of theology may provide obvious objects of study for legal theology. Here are three examples-ecclesiology, dogmatic theology, and biblical theology-that might also help us to locate legal theology.

I See Norman Doe, Christian Law: Contemporary Principles (Cambridge: Cambridge University Press, 20I3). 


\section{Ecclesiology}

Ecclesiology, the study of the church, explores the origins, nature, and purposes of the church universal. Its methods include developing categories for the attributes of the church, such as one holy catholic and apostolic, and the people of God. One aim of ecclesiology is to understand what may be authentic, required, permissible, or appropriate church structures, such as those in ministry, government, discipleship, evangelism, worship, and teaching. ${ }^{2}$ As such, each tradition has developed its own ecclesiology (also today the subject of ecumenical dialogue). Legal theology could be understood as a branch of ecclesiology. It is common today to see church law-order-polity as applied ecclesiology, and therefore to speak of a "theology of church law" and "theology in church law." 3 The former is a doctrinal (perhaps speculative) exercise, and the latter is a more descriptive and perhaps scientific exercise. One aim of legal theology could be to develop these two categories through the study of such provisions in the regulatory instruments of churches as, for example, from the Orthodox tradition: a church (which may be part of a worldwide Patriarchate), exists "to proclaim the Gospel of Christ, to teach and spread the Orthodox Christian Faith, to energize, cultivate and guide the life of the Church," to sanctify "the faithful through Divine Worship," to build up "the spiritual and ethical life of the faithful," and to serve as a "witness of the message of Christ to all persons." 4 Likewise, in the Protestant traditions, a Lutheran church exists as "part of the whole Church of Christ," to "declare the teachings of the prophets and apostles," "to confess ... the faith," and to engage in "worship and Christian service." 5 Legal theology may be developed to test the claims of ecclesiology against the reality of church legal orders.

\section{Dogmatic Theology}

The object of study in dogmatic theology (or dogmatics) is the creeds or statements of faith (that is, dogma, teaching, doctrines, and confessions) of churches. It seeks a systematic arrangement of the articles of faith; or it is the branch of theology that deals with them. Dogmatic theology helps to test our own beliefs for coherence and rationality. ${ }^{6}$ The dogmas, articles, confessions, and so on, of institutional churches (and of the traditions to which they belong) are the object of regulation (from their creation, through their redefinition, to doctrinal discipline in terms of assent to and dissent from them). Legal theology could test the dogmatic quality of church laws and should recognize also the normative quality of such dogmatic instruments as a means to regulate both belief and action. Typical of norms appearing in church juridical texts, which might inform such study, are those of the Methodist Church of Great Britain: "The doctrines of the evangelical faith, which Methodism has held from the beginning, and still holds, are based upon the divine revelation"; the Methodist Church acknowledges this revelation as "the supreme rule of faith and practice"; moreover, the Conference is "the final authority within the Church with regard to all questions concerning the interpretation of its doctrines"; but it cannot alter fundamental doctrines.7

2 See, for example, Avery Dulles, Models of the Church, 2nd ed. (Dublin: Gill and Macmillan, I987).

3 For a Roman Catholic perspective, see, for example, Robert Ombres, "Canon Law and Theology," Ecclesiastical Law Journal I4, no. 2 (2014), I64-94.

4 Charter of the Greek Orthodox Archdiocese of America (2003), art. 2.

5 Evangelical Lutheran Church in America: Constitution and Foundational Texts (2003), chapters I-4, 8.73.

6 See, for example, Karl Barth, Church Dogmatics: A Selection (Louisville: Westminster John Knox Press, I994).

7 "Deed of Union," in The Constitutional Practice and Discipline of the Methodist Church, vol. 2 (London: Methodist Publishing, 20I6), section 2, paras. 4-5, pp. 213-24. 


\section{Biblical Theology}

Biblical theology, or bibliology, takes a particular subject and explores what the Bible teaches on it. It emphasizes the historical context in which the author wrote, may recognize that God self-reveals differently at different times in history, and seeks to understand how this is demonstrated in the progression of the Bible. Bibliology explores the nature of the Bible as, for example, inspired Word of God, and the development of the scriptural canon. ${ }^{8}$ Legal theology could explore under this head the treatment of the Bible as an object of regulation within churches, such as how laws present the Bible (for example, as the inspired Word of God), use it as a defining element of the juridical identity of a church, and how church legislators and others use the Bible as a material source for the creation of laws. For example, the Lutheran Church of Australia recognizes "the Holy Scriptures ... as the only infallible source and norm for all matters of faith, doctrine and life"; its laws often cite passages from Holy Scripture; ${ }^{9}$ and in the Lutheran Church Missouri Synod, if a rule contradicts scripture, it does not bind: "no resolution of the Synod imposing anything upon the individual congregation is of binding force if it is not in accordance with the Word of God or if it appears to be inexpedient as far as the condition of a congregation is concerned." ${ }^{\mathrm{IO}}$

\section{THE METHODS OF LEGAL THEOLOGY}

The dominant feature of several branches of theology is that of their method as applied to a particular theological topic or issue. These methods, too, may inform legal theology taking it beyond the standard juristic method in church law of description, explanation, and evaluation.

\section{Systematic Theology}

Like biblical theology, systematic theology uses the Bible as its main object of study. However, systematic theology offers distinct methods of biblical analysis, for example, to compare all of scripture so as to create a systematized statement on what the whole Bible says about particular issues. While biblical theology may see the divine self-revelation in a progressive manner, systematic theology seeks to present God and revelation in a way that transcends history and to construct a system of theological propositions that are internally consistent. ${ }^{\text {II }}$ Legal theology might in its use of law and theology attempt to compare and relate all the laws of different churches and create a systematized statement on what all these laws provide about particular issues so as to transcend denominational affiliations. This method would have ecumenical merit in providing the total picture of juridical Christianity. It has been argued recently that, when compared, there are profound similarities between the basic elements of the normative regimes of the churches across the ecclesiastical traditions worldwide. From these similarities may be induced common principles of Christian law. When compared systematically, these regulatory systems also tell us much about convergence in action, based on common norms of conduct. While dogmas may divide churches, the profound similarities between their norms of conduct produce juridical convergence. This

8 See, for example, James D. Smart, The Past, Present and Future of Biblical Theology (Philadelphia: Westminster, I979).

9 Lutheran Church of Australia Inc., Constitution (2015), art. 2.I; see also ibid., art. 4.I, citing I Corinthians 6.

Io The Lutheran Church-Missouri Synod, Constitution (2010), art. 7; The Lutheran Church-Missouri Synod, By-laws (2010), para. I.7.

I I See, for example, Paul Tillich, Systematic Theology, 3 vols. (Chicago: University of Chicago Press, I95 I-I963). 
reveals that the juridical norms of the faithful, whatever their various denominational affiliations, link Christians through their stimulation of common forms of action. As laws converge, so actions converge. While there are key differences, similarities between the norms of conduct of churches indicate that their faithful engage in the visible world in much the same actions as other Christians. The articulation of principles of law-order-polity common to the churches: enables the reconciliation of juridical difference in the form of underlying principles of law; provides a stable ecumenical methodology through its focus on concrete textual data; offers a practical guide for Christian life; and defines that degree of achieved communion, as well as opportunities for and limits on future progress. ${ }^{\mathrm{I} 2}$

\section{Exegetical Theology}

Exegetical theology seeks to "bring out" truths of scripture by discovering what the message would have meant to its original audience (and author). It may address what a portion of Scripture says about a particular matter, and it uses the rules of exegetical analysis to draw out meaning. Its methods include hermeneutics, the historical and cultural context of the material, the literary style, original language, and placing one passage with other passages. Once the original message, purpose, and intent of a passage, is determined, exegesis may also seek to apply that timeless truth of scripture to people today. ${ }^{\mathrm{I} 3}$ It would be fascinating to explore, for example, what impact principles of exegetical theology might have on the very practical norms currently used by churches to interpret their own laws; for instance, in the Roman Catholic Church, laws are "to be understood in accord with the proper meaning of the words ... in their text and context"; ${ }^{\mathrm{I} 4}$ similarly, for Anglicans worldwide, if "the meaning of laws remains in doubt recourse may be had to analogous texts, the purposes and circumstances of the law, the mind of the legislator, the jurisprudence of church courts and tribunals, the opinion of jurists, the principles of canon law and theology, the common good, and the practice and tradition of that church and of the church universal." I5

\section{Pastoral Theology}

Pastoral theology (sometimes known as practical theology or applied theology) focuses on the day-to-day application of theology in the lives of Christians or churches and issues they face. A typical method is the pastoral cycle, in which the participant identifies a particular issue in life, reflects upon it theologically, deploys the results of that theological reflection, and develops an action plan in relation to that issue. All areas of church regulation would be suitable for this theological method. For example, pneumatology, the object of which is the Holy Spirit (and its interaction with the world), would also be relevant here, not least in terms of how laws portray and accommodate the work of the Holy Spirit. From a field such as church discipline, the Methodist Church in Ireland provides "Discipline in the Church is an exercise of that spiritual authority which the Lord Jesus has appointed in His Church. The ends contemplated by discipline are the maintenance of the purity of the Church, the spiritual benefit of the members and the honour of our Lord"; moreover,

I2 Doe, Christian Law.

I3 See, for example, Frances M. Young, Biblical Exegesis and the Formation of Christian Culture (Cambridge: Cambridge University Press, I997).

I4 Code of Canon Law (I983), canon I7.

I 5 Principles of Canon Law Common to the Church of the Anglican Communion (London: Anglican Communion Office, 2008), principle 8.I-4. 
"All members and Ministers of the Church are subject to its government and discipline, and are under the jurisdiction and care of the appropriate Courts of the Church in all matters of Doctrine, Worship, Discipline, and Order in accordance with the Rules and Regulations from time to time made by the Conference" (the central governing body). ${ }^{\mathrm{I} 6}$ The application of each element of this understanding of church discipline in any particular disciplinary process could fruitfully involve identifying the mischief at hand, theological reflection on the gravity of the offense, the role of forgiveness, and the decision whether to impose a just censure.

\section{THE PURPOSES OF LEGAL THEOLOGY}

As we have seen, each branch of theology has its own purposes-though the purposes of some branches are more conspicuous than those of other branches (which may be classified as less substantive and rather more about method). Some branches of theology seek to transform not only ways of thinking and belief, but also action in the world. These, too, may be adapted to the particular concerns of legal theology as it applies to the laws of churches.

\section{Natural Theology}

The focus of natural theology is general or natural revelation. ${ }^{17}$ It begins with observations of creation and suggests that, as God created in a way that is consistent with his own nature and character, so we might infer genuine truths and ethical positions from our observations. Legal theology should study not only relations between theology and positive law but the place of natural law thinking within the juridical framework of church life: whether there are principles of natural law overarching the legal systems of all churches across the Christian traditions, how these are ascertained, by whom, and with what effect. In the ecumenical context, natural law has already been a focus of discussion in dialogue between the World Alliance of Reformed Churches (now the World Communion of Reformed Churches) and the Roman Catholic Church, that latter of which proposes that "Reformed and Roman Catholics agree that discipleship to Jesus Christ entails the discernment of God's will regarding ethical issues and moral behavior"; moreover, both "acknowledge the contribution of human reasoning to moral and ethical discernment, although theologians and ethicists within our communities have at times evaluated in differing or even contrasting ways that philosophical understanding of good and evil usually called the 'theory of natural law.' As is well known, Catholic teaching affirms the possibility of knowing right and wrong actions on the basis of natural law." ${ }_{18}$ A recent ecumenical exploration suggests that the Christian traditions worldwide share far more in terms of a common understanding of natural law thinking than this document implies. ${ }^{19}$

I6 Constitution of the Methodist Church in Ireland (I927), section 5.

I7 Moral theology, or Christian ethics, is also pertinent here.

I 8 The Church as Community of Common Witness to the Kingdom of God: Report of the Third Phase of the International Theological Dialogue between the Catholic Church and the World Alliance of Reformed Churches (1998-2005) (2007), para. I40.

I9 See Norman Doe, ed., Christianity and Natural Law: An Introduction (Cambridge: Cambridge University Press, forthcoming). 


\section{Missiology}

Missiology focuses on the study of mission, how the church should spread the Gospel, and how the church should grow. One of its purposes is to convey how these matters should be conditioned by scriptures, cultures, psychology, trends, history, and demographics. ${ }^{20}$ Yet, there are few studies on how the laws of Christians address mission. However, regulatory instruments commonly make provision for mission. For example, the Standing Conference of the Canonical Orthodox Bishops in the Americas has mission commissions "to study the needs and opportunities of the jurisdictions in the external and internal mission fields of the Church, at home and abroad, to point out opportunities or failures, and to suggest areas in which necessary resources might be found." ${ }^{21}$ In the Ukrainian Orthodox Church in America, "The diocesan bishop ... is bound to propagate and expound Orthodox Faith and morals among all people within the diocesan boundaries." To accomplish this, the bishop is obliged to "ensure that his clergy make an Orthodox witness in their communities," "establish missions for the purpose of propagating the Orthodox faith," and "provide the necessary funds for missionary activity within his diocese." ${ }^{22}$ Here legal theology might engage how legal arrangements foster or frustrate the promotion of mission.

\section{Liberation Theology}

The focus of liberation theology is the plight of marginalized peoples. It proposes both a "theology of liberation," that is, freedom from institutionalized injustice, and the "liberation of theology" from the values of those who benefit from injustice. As to method, it is an interpretation of Christian faith out of the experience of the poor, that is, an attempt to read the Bible and key Christian doctrines with the eyes of the poor, and it relies on so-called proof-texts from scripture. One of its aims is to provide a theology-based program for social reform to liberate the marginalized from economic, political, and other forms of injustice. ${ }^{23}$ Legal theology could use the purposes of liberation theology - the transformation of unjust structures - as one of its own key purposes. The concepts of justice in liberation theology may provide yardsticks against which to measure the legitimacy of church laws, not least those that address the promotion of human rights in civil society and provision made by churches for social responsibility. Once more, the regulatory instruments of Christians worldwide address human rights and social justice. For example, as the Baptist World Alliance must defend human rights globally, ${ }^{24}$ so, too, at the national level Baptist Conventions and Unions recognize human rights and are "to maintain religious liberty." 25 Thus, the Baptist Union of Southern Africa accepts "that no individual should be coerced either by the State or by any secular, ecclesiastical or religious group in matters of faith" on the basis of "the right to interpret the Scriptures responsibly and to act in the light of his conscience." ${ }_{26}$ For the North American Baptist Conference, "Christians, individually and collectively ... [must] promote truth, justice and peace ... [and] aid the needy and preserve the dignity of all races and

20 See, for example, Lesslie Newbigin, The Open Secret: Sketches for a Missionary Theology (Grand Rapids: William B. Eerdmans, I978).

2I The Constitution of the Standing Conference of Canonical Orthodox Bishops in the Americas (I96I), art. 4.2; see also The Statutes for the Organisation and Functioning of the Romanian Orthodox Church, art. Io6.

22 Statutes of the Ukrainian Orthodox Church in America (2015), art. 7.I 2.

23 See, for example, Gustavo Gutierrez, A Theology of Liberation (Maryknoll: Orbis Books 1973).

24 Constitution of the Baptist World Alliance (2016), art. 2.

25 Constitution of the Baptist Union of Southern Africa (1933, subsequently amended), art. 5.3.

26 Baptist Union of Southern Africa, Model Constitution [for a member church], art. 4.2.6. 
conditions." ${ }^{27}$ The churches of the American Baptist Churches in the U.S.A. are to seek the mind of Christ on "political, economic, [and] social" matters and express this "to the rest of society." 28

\section{CONCLUSION}

The "fit" of legal theology to some branches of theology is more obvious than to other branches. Be that as it may, legal theology could be an interdisciplinary and collaborative branch of theology that draws on the objects of study, methods, and purposes of other branches of theology. One of its tasks, therefore, could be to explore the relationship between these theological subcategories-their objects, methods, and purposes-and the laws of churches across the various Christian traditions: that is, how these theological branches (their objects, methods, and purposes) may be teased out in the context of the churches' substantive laws as they apply to ministry, governance, doctrine, worship, rites, property, ecumenism, and the state and wider society. Such an exercise might include the aim of developing categories such as "juridical ecclesiology," "juridical ecumenics," "juridical dogmatics," "juridical apologetics," and so on. It would also be worth exploring how legal theology might feature in theological education in terms of the formation of ministers. Above all, legal theology would provide an opportunity for theologians to offer insights into the theological foundations of church laws and for jurists to provide concrete evidence both to test theological propositions in the practicalities of ecclesial life and to shape them.

27 Statement of Beliefs of the North American Baptists (I982, amended 2009), para. 8 (citing, for example, Matthew 5:I3-16, Hebrews I3.5, Luke 9.23, Titus 2.I2), https://nabconference.org/about-us/our-beliefs. 